\title{
Os símbolos das linguagens artísticas do Congado de Paula Cândido
}

\author{
Vanessa Lana ${ }^{1}$, Lorena Oliveira Vieira ${ }^{2}$, Flaviane Leite ${ }^{3}$
}

Resumo: A proposta deste artigo é apresentar e discutir os resultados do projeto de pesquisa intitulado "Os símbolos das linguagens artísticas do congado de Paula Cândido", realizado por meio do Programa Institucional de Bolsas de Cultura e Arte Universitária - Procultura, da Universidade Federal de Viçosa. O projeto analisou, através de pesquisa documental, observação participante e realização de entrevistas, os simbolismos e rituais do congado na Festa de Nossa Senhora do Rosário, buscando perceber as linguagens artísticas da celebração, o envolvimento e significados para a comunidade local. Como resultado do projeto, foi elaborada e distribuída uma cartilha, como atividade extensionista, discutindo cultura, congado e tradições.

Palavras-chave: Congado. Simbolismo. Cultura. Tradição.

Área Temática: Cultura. Patrimônio.

\section{The symbols of the artistic languages in Paula Cândido's congado}

Abstract: This article proposes to present and discuss the results of the project entitled "The symbols of artistic languages of Paula Cândido's Congado" ("Congado" is a brazilian word that means a cultural and religious african-brazilian manifestation party), accomplished by the Institutional Program of Culture and University Art Scholarships by Federal University of Viçosa, Brazil. The project analyzed, through documentary research, participant observation and interviews, the congado's rituals and symbols at Nossa Senhora do Rosário's party, a typical party that happens in the city of Paula Cândido, aiming to perceive the artistic languages of the celebration, beyond the involvement and meanings to the local community. As the project results, as an extension activity, primers discussing culture, tradition and the congado were elaborated and distributed.

Keywords: Congado. Symbolism. Culture. Tradition.

\section{Los símbolos de los lenguajes artísticos del congado de Paula Cândido}

Resumen: La propuesta de este artículo es presentar y discutir los resultados del proyecto de investigación titulado "Los símbolos de los lenguajes artísticos del congado de Paula Cândido", realizado por medio del Programa Institucional de Becas de Cultura y Arte Universitario - Procultura, de la Universidad Federal de Viçosa. El proyecto analizó, através de la

\footnotetext{
${ }^{1}$ Professora Doutora do Departamento de História da Universidade Federal de Viçosa - UFV, Viçosa - MG, Brasil. Professora do Mestrado Profissional em Patrimônio, Paisagens e Cidadania / UFV. Endereço: Avenida Peter Henry Rolfs, s/n - Campus Universitário, 36570-900 - Viçosa-MG - Brasil. Telefone (31)3612 7433. Email: vanessalana@ufv.br.

${ }^{2}$ Graduada em História pela Universidade Federal de Viçosa. Professora da Rede Estadual de Ensino de Minas Gerais. E-mail: lorenahist2014@gmail.com.

${ }^{3}$ Mestre em Patrimônio Cultural, Paisagens e Cidadania pela Universidade Federal de Viçosa. Técnica em Restauração / Universidade Federal de Viçosa. E-mail: flavianeleite@gmail.com.
} 
investigación documental, observación participante y entrevistas, los simbolismos y rituales del congado en la Fiesta de Nuestra Señora del Rosario, buscando percibir los lenguajes artísticos de la celebración, el envolvimiento y significados para la comunidad local. Como resultado del proyecto, como una actividad de extensión, se elaboró y distribuyó una cartilla discutiendo cultura, congado y tradiciones.

Palabras clave: Congo. Simbolismo. Cultura. Tradición.

\section{INTRODUÇÃO}

O presente artigo analisa o desenvolvimento do projeto "Os símbolos das linguagens artísticas do congado de Paula Cândido”. Paula Cândido é uma cidade da Zona da Mata Mineira, com aproximadamente dez mil habitantes. Está localizada a $25 \mathrm{~km}$ de Viçosa e a aproximadamente $240 \mathrm{~km}$ de Belo Horizonte. Na cidade acontece, ininterruptamente, desde 1853, a Festa de Nossa Senhora do Rosário, na qual a banda de congos tem uma participação importante e simbólica, representando a cultura afro-brasileira no interior de Minas Gerais. A religiosidade no estado, como explica Queiroz, se constituiu de forma singular, sendo mais independente de autoridades eclesiais e muito devota a santos. No entanto, a estrutura social que se iniciou no período colonial ditou algumas especificidades e hierarquias a esse catolicismo, que são representadas na festa religiosa (QUEIROZ, 2013).

O aporte metodológico da pesquisa foi composto por trabalho de campo na comunidade de Paula Cândido e nos eventos que envolvem a Festa do Rosário, desde os preparativos até o acontecimento da festividade. Realizamos pesquisa documental na Casa de Cultura Padre Antônio Mendes. Trabalhamos ainda com entrevistas realizadas com metodologia da História Oral, que constam do banco de dados da pesquisadora Flaviane Leite no trabalho "Linguagens do Vestuário: as transformações na indumentária das celebrações do congado de Paula Cândido-MG”.

A Festa do Rosário teve início no final do século XIX, período no qual a cidade de Paula Cândido era marcada por intensa religiosidade, sendo um município propriamente escravista. A construção da igreja-sede para a festa foi realizada por meio de doação de fazendeiros locais e da organização da própria comunidade para a realização das obras. Para arrecadar mais fundos, a primeira festa foi feita com a igreja inacabada (as obras duraram até 1862), e foi composta principalmente por negros escravos - reis, rainhas, criadas, juízes -, informações que puderam ser obtidas nas atas das primeiras festas, na Casa de Cultura Padre Antônio Mendes. Registros fotográficos, já de 1936, como mostra a Figura 1, quando os brancos tomaram a frente da festa em todos os sentidos, mostram que a maior parte dos negros usavam branco e estavam descalços, já que sapato naquela época era, assim como ter escravos, uma questão de status. As roupas naquela ocasião eram pouco enfeitadas e os participantes estavam em número reduzido. Na organização da festa, a celebração era realizada em um só dia, aglutinando procissões, missa e a chamada da mesa (momento de arrecadação de donativos para a construção da igreja). 


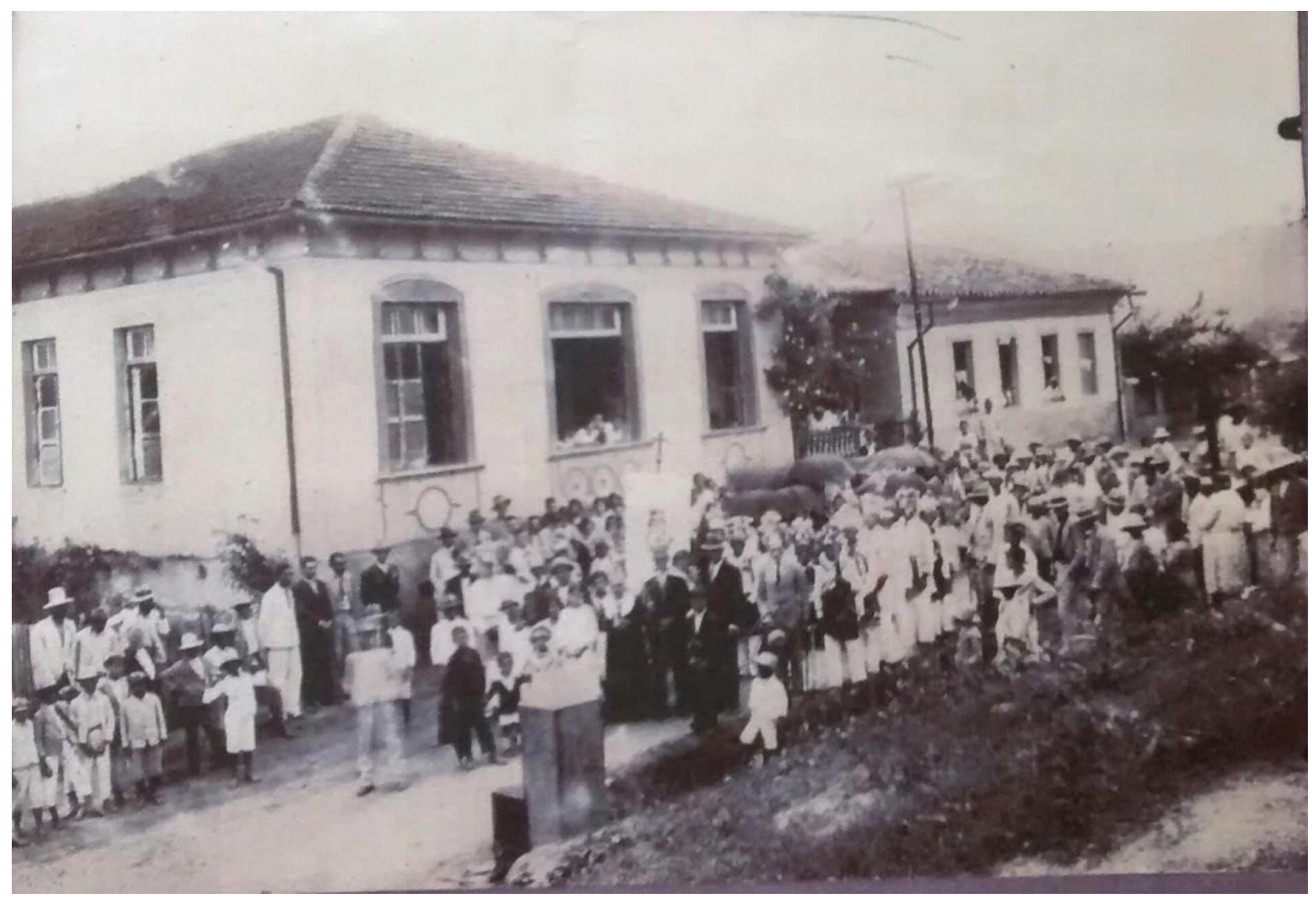

Figura 1. Foto da Festa do Rosário de 1936.

Fonte: Emerson Lisboa/ Arquivo Particular.

Segundo Bastide (1971), certa manifestação por parte dos escravos era tolerada para que a escravidão se mantivesse:

A catequização jesuíta partia da ideia de que era preciso adaptar o dogma à mentalidade e que a mentalidade dos negros é a mesma das crianças. É preciso atraí-los pela música que adoram, pela dança, que é sua única distração, pela vaidade, o amor aos títulos, aos cargos decorativos. Não é preciso romper absolutamente com seus costumes tradicionais, mas fazer uma seleção deles, e dos que são considerados aceitáveis, servir-se deles como de um trampolim para levá-lo até a verdadeira fé (BASTIDE, 1971: 171-172).

Os negros utilizavam essa tolerância dos senhores como um meio de resistência às imposições, não só como mera aceitação. Pensando nisso, incluir o congado como proposta de análise, que fazia parte da festa e era uma importante expressão cultural afro-brasileira, é importante para percebermos sua presença e seu desenvolvimento ao longo da festividade. $O$ fato de elas serem toleradas não significa que os escravos não tinham consciência do que era feito ou ainda que não se utilizassem disso a seu favor, eles não eram passivos diante da escravidão e de tudo que lhes era imposto, muito pelo contrário. Os congos batiam tambor, se vestiam de branco, dançavam de uma maneira única enquanto expressavam sua força e sua insatisfação com a sociedade escravocrata. Desse modo, a participação na festa de Nossa Senhora do Rosário, ainda que o negro tivesse papel importante, foi sendo marcada por momentos que demonstravam a relação de poder intrínseca àquela organização social. 
A banda de congo não entrava na igreja, tocava o tempo todo do lado de fora. Suas canções, não menos expressivas, pediam bênçãos aos santos negros, contra a dura realidade dos escravos. Dessa forma, o congado foi incorporado à festa e, com o passar do tempo, a festa foi se modificando. A primeira mudança, de acordo com as atas registradas, foi a diminuição da participação dos negros. Cinquenta e três anos após o início da festa, sob a justificativa de falta de dinheiro, têm-se os primeiros reis brancos, que, a partir daquele momento, bancariam sua própria festa. As roupas, a partir daí, passaram a ser mais incrementadas, pomposas, mas não menos sóbrias, mantendo suas cores e vivacidade, mostrando novamente a relação de poder que havia, dividindo pretos e brancos de acordo com sua participação na celebração. Anos depois, a festa passou a ser feita em dois dias diferentes, mas sempre no final de outubro - já que esse é o mês em que se comemora a santa que representa a festa (LEITE, 2019).

$\mathrm{Na}$ atual forma de organização da festa vemos que, ainda que o congado tenha papel importante a desempenhar nos cortejos, ele ainda está subordinado à entidade religiosa. Tal questão pode ser observada pelo fato de eles não adentrarem a igreja durante as missas e não cantarem no levantamento do mastro. Seu trabalho é guarnecer as rainhas e levá-las em segurança até a igreja ou até suas casas. Tal aspecto pode ser observado quando os Corta- Ventos, que são membros da guarda, batem as espadas. Além disso, toda a composição do congado mostra que sua função é proteger as rainhas, reis e suas criadas. E isso é fruto de uma construção histórica:

Embora de natureza similar, a estrutura da família patriarcal escravista inibia o igualitarismo cristão das duas partes: os negros não eram admitidos nas capelas, permanecendo do lado de fora, mas celebravam o fim da missa cantando um hino, às vezes em sua língua, de forma que seu catolicismo foi, como as religiões africanas, em certa medida, uma subcultura de classe. A partir disso, caracterizouse uma construção de identidade não só negra, mas também católica (QUEIROZ, 2013: 18).

Toda a festa, portanto, desde 1853 foi ressignificada de acordo com as próprias transformações da sociedade e de seus códigos culturais. Fez- se necessário usar calçados, abusar das cores, incrementar a música com mais instrumentos, organizar melhor o cortejo fazendo, por exemplo, com que todos os criados, assim como os reis, usassem guarda-chuvas, tornando a festa mais popular. Cada pároco que coordenou os trabalhos da Igreja fez uma modificação: foi o Padre Duarte, por exemplo, que por volta de 1917 implantou o terço durante o mês de outubro (QUEIROZ, 2013).

Aigreja exerceu um importante papel na manutenção de seus devotos. Tornar a festa popular foi parte disso. Quanto mais pessoas participavam da festa, mais pessoas iam à igreja, e a própria arrecadação de donativos era maior. De acordo com as atas e escritos não oficiais sobre a história da festa, disponíveis para pesquisa na Casa de Cultura, as espórtulas arrecadadas depois da construção da Igreja serviram para construir a Fundação Municipal de Saúde de Paula Cândido - não mais o arraial de São José do Barroso. Depois disso, aquilo que era arrecadado pagava custos da festa, sendo o restante doado para instituições de caridade do município.

O congado, portanto, possui uma tradição específica na cidade, no sentido de ter características próprias, que foram obtidas ao longo dos mais de cento e sessenta anos de existência e outros tantos de tradição. Alguns 
gestos, o ensaiado jogo de poder, a hierarquia intrínseca entre crenças, a dança, o canto, o vestuário, tudo isso é objeto da nossa análise. Não nos interessa os "porquês" somente, mas o "como", o "onde" e o "quando", indagações que devem ser feitas para que se entenda o objetivo último do estudo: o simbolismo que está interno.

Desse modo, o projeto buscou investigar, a partir da observação dos preparativos e do decorrer da festa, a importância, os significados e ressignificados que a prática do congado na Festa do Rosário tem para seus membros, para a religiosidade e para a cultura da cidade. Observar que todo o fazer artístico do grupo pode nem sempre ser (re)pensado, tornando a participação o seguimento de uma tradição, mas que ela tem sua forma de ser compreendida por cada membro, entendida por todos e nem sempre vista como arte.

Assim, para discutir as hierarquias presentes na festa e seus símbolos, na primeira parte do artigo, apresentaremos os objetivos da pesquisa. Em seguida, após apresentação da metodologia, será destacado como os objetivos do projeto foram colocados em prática, destacando os símbolos da banda de congos, a vestimenta, a música e a dança. Por fim, discutiremos aspectos da festa realizada no ano da pesquisa, em 2017, e a construção e divulgação da cartilha como produto final do trabalho.

\section{OBJETIVOS}

O presente artigo tem como objetivo apresentar e discutir o projeto "Os símbolos das linguagens artísticas do congado de Paula Cândido", desenvolvido no ano de 2017, no Departamento de História da Universidade Federal de Viçosa. O projeto foi realizado a partir do Programa Institucional de Bolsas de Cultura e Arte Universitária - Procultura. A proposta foi refletir, sob uma perspectiva interdisciplinar, sobre a importância e os simbolismos intrínsecos ao congado da cidade de Paula Cândido, analisando as rupturas e permanências da tradição para a comunidade local. O projeto teve como objetivo resgatar as tradições presentes no festejo religioso, a partir das visões da própria comunidade, aproximando a produção de conhecimento na universidade ao conhecimento e hábitos culturais da população local.

Tendo em vista esses aspectos, o projeto visou observar, para além das características do festejo, as intencionalidades na organização e apresentação do mesmo, e as percepções na perpetuação das tradições. Para tal, a observação dos símbolos - vestimenta, como era usada, em quais momentos, quais elementos a compunha; da música, a partir da análise das letras, se havia uma escolha prédefinida do repertório, quais instrumentos era usados e da dança, se atentando para os movimentos e a ligação deles com a natureza - foi o ponto-chave para a análise.

\section{METODOLOGIA}

Para o desenrolar da pesquisa, buscando compreender os aspectos acima destacados, as primeiras ações foram baseadas em um trabalho de campo, com o objetivo de mapear arquivos que permitissem analisar o surgimento da Festa do Rosário e da banda de congos na cidade. Recorremos a ambientes e pessoas que 
estavam envolvidos com a história do congado. O primeiro deles foi a Casa de Cultura da cidade - Casa de Cultura Padre Antônio Mendes - que é um ambiente que guarda as memórias da cidade, expondo fotos, documentos e objetos que marcaram a história de Paula Cândido, além de promover exposições culturais para a comunidade. A partir da pesquisa na Casa de Cultura foi possível tecer uma rede de contatos, na qual pudemos nos comunicar com alguns congos, costureiras e o antigo secretário de cultura, que nos ajudaram na pesquisa e na organização da observação participante. Entre os documentos coletados estavam as atas dos primeiros anos da festa, registro de sepultamento de escravos e outros moradores, fotos das festas do Rosário e trabalhos acadêmicos de cronistas locais.

Tanto as atas quanto o registro estavam incompletos, com algumas páginas soltas e todo manuscrito. Estes foram os documentos mais antigos que tivemos acesso, e nos permitiram compreender o início da festa na cidade e o contexto social local da época. Os arquivos mais recentes nos ajudaram a entender como se deu a continuidade da banda, o registro em cartório do grupo mais antigo, a convivência com os congos, que permitiram conhecer a nova banda e compreender a divisão da primeira guarda em duas, fato que já ocorre pela segunda vez desde sua criação.

A observação participante se deu pelo acompanhamento dos preparativos do congado, como alguns ensaios para a Festa do Rosário e durante o evento, com as procissões, escolta dos reis, e apresentações na praça durante as missas. Neste acompanhamento, pudemos observar o uso de vestimentas diferentes para determinados momentos, podendo analisar de perto os aspectos que caracterizam essa participação. Também foi possível observar aspectos como a dedicação e o envolvimento dos membros da banda, o comportamento em cada momento de apresentação, o uso de diversos instrumentos e a não obrigatoriedade no uso do uniforme em certas apresentações, marcando momentos menos formais dentro da festividade.

Outra frente de pesquisa foram entrevistas (Comitê de Ética em Pesquisa com Seres Humanos da Universidade Federal de Viçosa. Parecer de Aprovação n ${ }^{\circ}$ 2.058.810) realizadas pela pesquisadora Flaviane Leite, no trabalho de mestrado intitulado "Linguagens do Vestuário: as transformações na indumentária das celebrações do congado de Paula Cândido - MG”, no Mestrado em Patrimônio Cultural, Paisagens e Cidadania do Departamento de História da Universidade Federal de Viçosa. Esse material nos permitiu coletar informações sobre a história e a importância da banda, percebendo seus significados para os envolvidos com a festa.

\section{RESULTADOS E DISCUSSÃO}

O projeto “Os símbolos das linguagens artísticas do congado de Paula Cândido" buscou destacar aspectos e narrativas históricas que foram inseridos de forma simbólica na manifestação artística do congado (música, vestuário, dança etc.). Através da análise dos significados desses símbolos e sua intencionalidade, buscamos compreender como os participantes do congado se relacionaram com essa linguagem, observando se essa faz parte do seu imaginário, de forma consciente ou não. 
A indumentária utilizada pelos participantes do congado de Paula Cândido destaca-se pelo fato de serem confeccionadas com diversas cores e acessórios de diferentes aspectos e materiais. Assim, a análise da indumentária nos permite perceber que mesmo mantendo os elementos que caracterizam o vestuário, como uniforme com fitas e capacetes enfeitados, estes vão se modificando de acordo com as necessidades do momento no qual foram construídos.

Desta forma, na confecção das vestimentas, novos materiais são utilizados, podendo essas modificações estarem relacionadas à interferência dos envolvidos na festa, à economia, e também a questões identitárias do grupo. Algumas peças utilizadas em festas anteriores são reaproveitadas, podendo ser transformadas em detalhes de outros objetos para as próximas festas. Como exemplo, tecidos de motivos africanos utilizados pela rainha de uma das festas foram transformados em capacetes para festas futuras. Este fato relaciona-se com a economia, mas também a ele está atrelada a intenção de incorporar ao vestuário do congado símbolos que remetem à descendência africana e apontam, ainda, para a manutenção de tradições no decurso da festividade.

A escolha por analisar também as músicas e toda sua composição se deu por sua particularidade na celebração do congado. Ao trazer consigo a cultura negra de matriz africana, expressa nas palavras de origem e nos ritmos, a dança abarca todos os participantes e se apresenta como uma expressão corporal diante da música que é tocada. O ritual envolve espadas e toda uma coreografia que circunda os participantes principais, marcando pontos importantes da festa, como a saída e entrada nas igrejas e a procissão pelas ruas.

O grupo de congado da cidade, apesar de por vezes seguir a tradição ao se portar sempre da mesma forma diante dos rituais, se permitiu incrementar e popularizar sua prática musical abrindo espaço para novos instrumentos, não utilizados por outros grupos. A sanfona, o violão e a viola quase não são ouvidos em meio a tantos pandeiros e tambores, mas ao observarmos as apresentações com mais atenção percebemos que os sons de todos aqueles instrumentos juntos dão um ritmo especial a cada música. Os novos instrumentos também abriam espaço para que diferentes instrumentistas participem da guarda, o que contribui na popularização do congado no município.

As letras também não seguem um padrão. Por não haver necessariamente um registro escrito destas músicas, os membros aprendem a cantar com os mais velhos. As músicas cantadas não têm necessariamente um título e são proferidas durante toda a festividade. Desse modo, é comum percebermos que alguns congaleiros cantam os versos usando palavras diferentes em cada momento. Em uma delas, por exemplo, no primeiro verso alguns cantam "Cai céu sereno..." enquanto outros cantam "ô céu sereno...”, e no segundo verso ainda é possível notar uma outra diferença quando os membros usam a expressão “cai, cai sereno” (Música entoada pela banda de congos Nossa Senhora na Festa do Rosário de 2017). Pode ser uma simples variação entre cada verso ou uma indicação que não há uma regra rígida a ser seguida quando o assunto é louvar Nossa Senhora do Rosário, e cada um pode aprender e expressar a canção e a religiosidade a seu modo. 
Algumas músicas também indicam como é a expressão dos congaleiros na dança. Em uma delas é indicado "pisa no chão com força, pisa no chão devagar, vou pedir Nossa Senhora que ela vai nos ajudar" (Música entoada pela banda de congos Nossa Senhora na Festa do Rosário de 2017), que remete aos passos tradicionais que vemos no congado, em que os membros pulam, com maior ou menor intensidade, de um lado para o outro, como se estivessem cruzando as pernas. Nesse aspecto, também não é possível notar uma regra, cada um pula a seu modo, enquanto uns pulam na mesma posição, outro pulam somente de um lado para o outro, as vezes girando o corpo. Apesar de não haver uma determinação restrita para a prática da música e da dança, todos os membros têm consciência que, ao participar de uma guarda de congos, eles devem adotar uma espécie de conduta nas apresentações, tanto ao dançar quanto ao cantar, que respeite as características gerais do grupo e da festa.

No ritual da festa, os ensaios aconteciam nas tardes de domingo em uma rua da cidade. A banda de congado tocava por cerca de três horas, fazendo interrupções para descanso e distração. Em volta deles, os moradores se juntavam para acompanhar os ensaios. Parecia uma antecipação da festa, pessoas sentadas na calçada conversando, comendo, crianças brincando e os meninos do congado intercalando a diversão com as responsabilidades da preparação da festa. Em meio a isso, era possível conversar e ouvir o que os membros pensavam e o quanto eles compreendiam sobre o congado. Não acompanhamos o fazer das roupas porque elas são, em sua maioria, reaproveitadas dos anos anteriores, somente algumas capas e chapéus foram feitos na véspera, todos utilizando tecidos reaproveitados, alguns do reinado de 2013 (o qual teve reis negros após 150 anos com reinados brancos).

O congado em Paula Cândido se consolidou nessa comunidade e tornou-se parte dela. Isso é verificado na sua participação efetiva na celebração de Nossa Senhora do Rosário, marcando momentos importantes e conduzindo as procissões. O grupo de congado traz uma identidade baseada na ancestralidade e na própria construção do município, carregando uma bagagem histórica com a festa e com a própria cidade.

Todos os símbolos presentes na banda estão diretamente relacionados à interação com a religião católica e, evidentemente, com a cultura africana. Queiroz (2013) afirma que a inserção do congado com o catolicismo assimilou uma nova analogia, pois:

Ao exercer o papel de disciplinadora e de intermediadora da comunidade negra com a sociedade, a Igreja, tem, hoje, uma influência muito maior do catolicismo no Congado, em algumas cidades, principalmente nas regiões mineradoras, caracterizando-o não como uma simples assimilação da cultura do outro, imposta como forma de domínio, mas como uma nova composição de símbolos e representações, que configuram uma “nova identidade” (QUEIROZ, 2013: 23).

A devoção por Nossa Senhora do Rosário e por outros santos, como Santa Ifigênia e São Benedito, mostram como os negros assimilaram o catolicismo e, ao mesmo tempo, mostra que essa assimilação se dá por uma representação, uma vez que esses santos são negros. Numa breve busca sobre a história desses santos, vemos, por exemplo, que Ifigênia ou Efigênia, era filha dos reis da Núbia, um reino da Etiópia; já São Benedito 
vinha da Itália, mas seus pais eram escravos e vinham da Etiópia também. É clara a relação entre a realidade dos santos e a realidade dos congos, sejam os de hoje ou os de 1853, com algumas ressalvas. A ligação com Nossa Senhora do Rosário é diferente, pois não se trata de identidade étnica, a relação é de devoção, uma vez que, de acordo com as entrevistas realizadas, foram os congaleiros que tiraram a santa de um rio ou de uma mata tocando seus tambores, depois de muitas outras tentativas por parte dos brancos de tentarem colocá-la em uma capela (Entrevistas projeto "Linguagens do Vestuário: as transformações na indumentária das celebrações do congado de Paula Cândido - MG”').

A Festa de Nossa Senhora do Rosário é tradição da cidade. Como já discutido, perpassa por sua história e sua expansão, e, assim como a festa do congado, se mostra importante para a constituição de uma cultura negra, de raiz afro, em um município tão pequeno. Não é nossa pretensão entrar na discussão de representação negra, mas é indiscutível que os congos são uma das primeiras identidades com as quais as crianças se reconhecem. Isso pode ser observado, dentre outros pontos, pela participação das mesmas na banda. Partindo desse pressuposto, podemos pensar sobre a ideia de patrimônio no congado de Paula Cândido, uma vez que "o sentido evocado ao termo patrimônio é o da permanência do passado, da necessidade de resguardar algo significativo no campo das identidades, do desaparecimento" (COSTA E CASTRO, 2008: 126). Ou seja, o patrimônio de uma comunidade é tudo aquilo com que ela se identifica, principalmente em suas referências culturais e simbólicas, e a memória está intimamente associada a esse conceito:

[...] vale lembrar que, enquanto patrimônio, esses saberes, costumes e modos de viver se ancoram
em memórias que circulam, física ou metaforicamente, entre os membros de um grupo e para serem
preservados devem permanecer simultaneamente ou alternadamente nas lembranças de todos
(COSTAECASTRO, 2008: 130).

Os costumes e modos de viver aos quais o autor se refere estariam ligados à constituição da cultura na memória, uma vez que as duas também estão atreladas. A memória está ligada às vivências importantes para cada pessoa ou pequenos grupos em um conjunto maior de pessoas que formam uma comunidade; o patrimônio seria a memória que circula entre todas elas. No caso de Paula Cândido, o congado é uma das memórias que circula entre um maior grupo de pessoas da cidade e, por isso, pode ser considerado um patrimônio. Nesse sentido, assim como o congado, a Igreja do Rosário também é um marco constitutivo da identidade do município.

Nesse sentido relembramos a discussão feita por Telles (2010), para a qual patrimônio cultural material e imaterial são indissociáveis, pois:

[...]não se pode conceber o dito patrimônio cultural material sem o significado que este carrega (que é imaterial), tampouco se pode verificar o patrimônio cultural imaterial sem pelo menos fazer referência, ou repercutir, a um suporte físico (que é material) ( TELLES, 2010: 124-125).

Congado, Festa de Nossa Senhora do Rosário e Igreja estão vinculados. Toda a celebração do congado gira em torno da igreja (material), a composição dos dois forma a festa. A igreja é o ponto central onde tudo 
acontece, é o lugar onde a banda não entra, é o entorno em que ela toca, é o ponto de encontro entre sagrado e profano, o local no qual ocorre o sincretismo. Essa característica pode ser pensada com o argumento de Roger Bastide, de que o catolicismo não teria conseguido firmar-se de maneira uniforme e definitiva, convergindo então para a existência de dois catolicismos - o do branco e o do negro. Essa separação também teria sido vivenciada pelas irmandades que também vivenciaram essa separação (BASTIDE, 1971).

Como o foco do trabalho foi analisar as expressões artísticas do congado, a confecção e utilização da roupa, as cores, os adereços, as letras das músicas, a escolha ou uso aleatório de cada uma delas, os ritmos, é possível argumentar que todos esses elementos geram uma imagem da festividade. E o viéis religioso, como discutido acima, é um dos preceitos formadores da mesma. Isso pode ser observado na letra abaixo:

[...] Ô cuenda-cuenda todo o povo

- Ô mãe Maria

Ô no rosário de Maria

- Ô mãe Maria

Ô cuenda príncipe e princesa

- Ô mãe Maria

Ô vamos todos pelejar

- Ô mãe Maria

E a Senhora do Rosário

- Ô mãe Maria

Que ela há de ajudar [...]

(Música entoada pela banda de congos Nossa Senhora na Festa do Rosário de 2017)

Esse é um trecho de uma das músicas que o congado canta para retirar o cortejo da igreja ou das casas das rainhas, a letra evoca o sentido de chamar aqueles que constituem a festa para a peleja, contando com a ajuda divina de Nossa Senhora do Rosário. Cuenda é a palavra que nos remete à língua africana, às origens de uma cultura misturada, e significa andar depressa. Essa música tem um ritmo mais lento, compassado por tambores e sem muito arranjo, quando o mestre canta a primeira estrofe, a segunda, “ô mão Maria” deve ser respondida pelo resto do grupo, numa entonação crescente, como se disse "Ô bombariá". Pontuamos, novamente, a dificuldade de entender as letras entoadas pelo congado, tanto pela entonação das palavras quanto pelo ritmo.

Algumas músicas mostram a proximidade com que o congado enxerga a Santa, indicando mais uma vez que fé tem a ver com representatividade também, além da relação ancestral que há entre a confraria e a devoção na Senhora do Rosário. Essas músicas têm sempre um ritmo contagiante, que chama atenção e alegra, mesmo quando as letras são mais melancólicas, e, por isso, as danças também seguem o compasso mais rápido e agitado. Elas remetem a animais e coisas da natureza, como por exemplo a dança do sapo, em que eles pulam agachados batendo espadas, ou a dança do grilo, em que eles pulam jogando os pés para trás.

A indumentária do congado, ilustrada na Figura 2, também foi se diversificando e se tornando mais acessível com o tempo. Ao não seguir necessariamente um padrão na cor e no modo de confecção, a customização 
da roupa se torna mais fácil, permitindo maior diversidade de cores e arranjos. A única exigência é que a calça e a blusa sejam brancas e o sapato também, preferencialmente. Alguns chapéus são feitos utilizando a chita, um tecido economicamente viável e que tem cores fortes e uma estampa geralmente floral, que tem muito a ver com os símbolos que a roupa traz. As capas também têm texturas e cores variadas, utilizando outro tecido barato, o cetim, que tem cores e brilhos que incrementam a vestimenta. Mas há na roupa algumas características que não mudam, como a cor azul e o uso de rosas artificiais nos chapéus, por representarem Nossa Senhora do Rosário, e das fitas coloridas nas capas e saias.

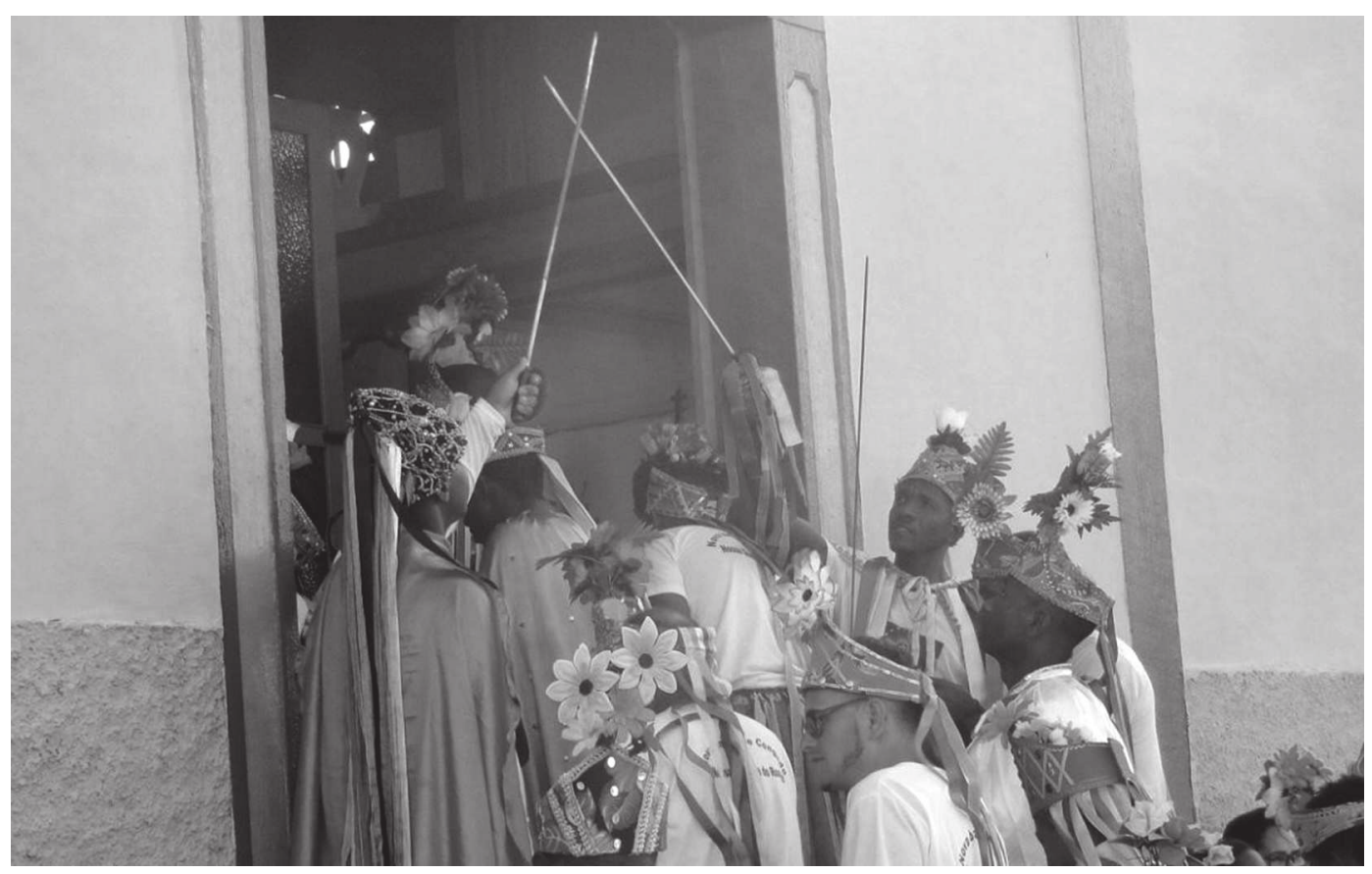

Figura 2. Foto de Congos batendo espada na porta da Igreja.

Fonte: Arquivo Pessoal.

O uniforme do congado só é usado a partir da primeira procissão do sábado, no segundo dia; na sexta feira e na madrugada do sábado eles usam roupas do dia a dia, casuais, mas que, de certo modo, respeitavam o ambiente de devoção. Essa troca de roupa marca os acontecimentos, os dias mais importantes da festa e aqueles em que é possível ser menos formal. Além disso, demonstra uma estratégia para que a roupa dure até o final, uma vez que eles utilizam o mesmo uniforme. A indumentária também serve para distinguir a hierarquia do congado; nem todos usam capas, somente os chefes e os corta-ventos. Elas são confeccionadas, tanto as roupas quanto os chapéus, pelas esposas dos congos, que as vezes se encarregam de fazer mais de uma peça, ou por costureiras da cidade.

Ao longo do trabalho de campo realizado durante a Festa de Nossa Senhora do Rosário, foi possível perceber que a celebração do congado perpassa sinais de rigor, força, divertimento e leveza. A postura concentrada dos participantes se mescla com a descontração na hora de cantar e dançar. No primeiro dia de comemorações 
ocorre, após a missa, o levantamento do mastro, atividade na qual três bandeiras são levantadas: a de Nossa Senhora do Rosário ao centro, a de São Benedito e Santa Ifigênia ao lado. Nesse momento, quem toca é a Corporação Musical Monsenhor Lisboa; o congado toca antes da missa e depois do levantamento. A comemoração retorna às quatro da manhã do dia seguinte com o congado acordando a cidade, e assim ele permanece o dia todo.

Antes da missa das nove da manhã o congado busca a "rainha velha", coroada no ano anterior - percebemos que o rei na festa tem papel coadjuvante, se comparado à rainha - e a leva, juntamente com suas criadas e guardas, à igreja. Enquanto a missa é celebrada os congos ficam do lado de fora cantando e dançando, entram somente para tirar os reis do trono e levá-la para o almoço. Às três da tarde a irmandade da Festa do Rosário faz, junto dos mesários, a chamada da mesa, momento em que são recolhidas espórtulas e a corporação musical toca a cada doação. Também durante essa hora o congado fica do lado de fora, tocando em frente à Casa Esperança, o asilo da cidade, e casas de antigos ou falecidos congos. Ao fim desse momento, congado e banda levam a rainha e suas criadas em procissão para sua casa.

O terceiro e último dia é o mais denso, às dez da manhã está marcada a primeira celebração do dia, então as duas bandas e a população (que nesse dia participa em maior quantidade) buscam as rainhas velha e nova, respectivamente, em suas casas. Durante a procissão, guardas de congo vão escoltando as rainhas com suas espadas, mostrando-lhes o caminho enquanto cantam e dançam - intercalando as músicas com a corporação. A missa é celebrada e então todos vão para o almoço oferecido pela rainha velha, não sem antes ouvirem alguns dobrados que a Corporação toca. Os congos são os primeiros a almoçarem e assim que terminam voltam a cantar incansavelmente. Novamente é feita a chamada, seguida de uma procissão até a Matriz, onde é realizada uma benção. Depois disso todos retornam à Igreja do Rosário para a troca das coroas, feita por cada uma das rainhas e reis, respectivamente. Já quase anoitecendo o congo retira o cortejo do interior e saem em procissão, rumo às residências de cada uma delas - velha e nova.

A partir das observações da Festa do Rosário de 2017 e das imagens captadas, produzimos um material, uma cartilha (Figura 3), que teve como proposta ilustrar e divulgar os resultados da pesquisa, numa ação extensionista, aproximando a universidade e a comunidade. A cartilha desenvolvida foi pensada para ter aplicação dentro das salas de aula da Educação Básica, propiciando a integração entre saber e cultura local e o conhecimento que se adquire nas escolas. De forma breve, o material reflete acerca da importância cultural do congado através de suas características, música, dança e vestimenta, propiciando ao leitor a percepção de certos traços que, na maioria das vezes, passam despercebidos aos olhos, não sendo valorizados pela maioria dos que acompanham a Festa de Nossa Senhora do Rosário, que foi o foco da observação. O material traz imagens que foram selecionadas pensando na ênfase de cada aspecto da festividade, discutidos ao longo desse texto. Buscamos instigar a observação e curiosidade do leitor, enfatizando a interação que o congado tem com o reinado (reis e rainhas que coroam a Santa do Rosário) adotando o papel de guarda. 

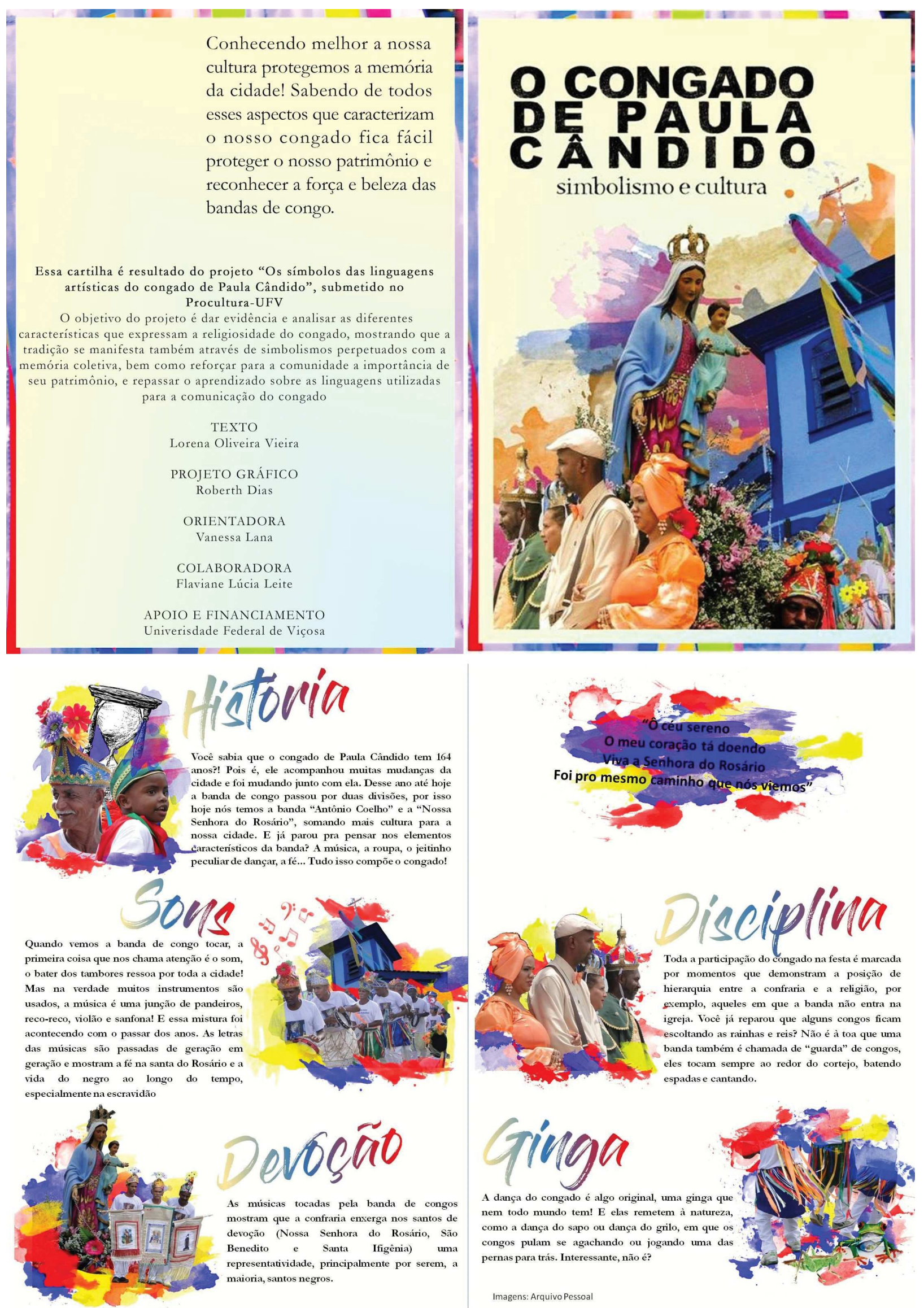

Figura 3. Cartilha produzida e distribuída na comunidade. 
A cartilha foi pensada para dialogar entre a pesquisa e o ensino, bem como com a comunidade em geral. Dessa forma, dialogaremos com essas áreas do conhecimento, integrando teoria e prática de acordo com o PNE, para o qual "a extensão universitária é um processo educativo, cultural e científico que articula o ensino e a pesquisa de forma indissociável e viabiliza a relação transformadora entre a universidade e a sociedade" (PNE, 1999). O projeto e o material elaborado corroboram com a premissa do Plano Nacional de Educação, pois, ao ser utilizado na sala de aula é possível transparecer alguns conceitos e seus significados e conectá-los à cultura local, especificamente ao congado e às tradições da comunidade.

O material teve utilização prática em uma turma do EJA da escola estadual da cidade de Paula Cândido, com a finalidade de discutir a importância cultural e patrimonial do congado a partir dos tópicos apresentados na cartilha. A aula teve início com uma apresentação da bolsista, do projeto e seus objetivos, e uma explicação de como foi feito o material. A partir da leitura dos tópicos nele expostos os alunos foram fazendo apontamento sobre o que eles já tinham visto e/ou sabiam. Com essa discussão foi possível incluir os conceitos de patrimônio e cultura, fazendo com que eles associassem significados aparentemente abstratos ao dia a dia, às festas da cidade. A conversa que se seguiu, sobre as experiências de cada um na Festa do Rosário, propiciou inserir outra definição, a de memória, e, a partir daí, concluímos os significados de cada palavra e a importância que o congado tem para a cultura local.

O projeto teve importância na comunidade para o (re)conhecimento e difusão de sua cultura que, por ser uma cidade de pequeno porte, por vezes é associada à ideia de que não possui nenhum bem ou evento, tendo como o maior e mais tradicional deles a Festa de Nossa Senhora do Rosário. A Festa carrega uma das maiores bagagens culturais da cidade, por agregar seus aspectos mais característicos: a fé católica, os talentos musicais e o artesanato. O projeto propiciou também o reconhecimento da importância da banda de congos para a festa e para a difusão da cultura negra na cidade. A banda de congos é a tradição mais antiga com a qual as crianças negras se reconhecem. Não por acaso, a banda recebe uma quantidade significante de crianças que tocam os pandeiros. A cartilha produzida, além de aplicada nas salas de aula, foi distribuída na Casa de Cultura Padre Antônio Mendes, em escolas do município e nas bandas de congo da cidade.

\section{CONCLUSÕES}

Ao longo da realização do projeto foi possível perceber que a guarda de congos da cidade de Paula Cândido tem significado importante para a cultura local. A banda não se insere em padrões rígidos, facilitando a participação e a permanência do grupo mesmo com poucos recursos. Assim, ao longo dos anos, ela aglutinou diferentes instrumentos, estampas e cores e recebeu pessoas de todas as idades, tendo chamado a atenção, em dado momento, pela grande quantidade de crianças. No entanto, a banda mostra seu apego à tradicionalidade 
ao não receber mulheres em seu meio e seguir, na maioria das vezes, uma ordem hereditária na formação de sua diretoria.

Foi possível perceber também que para a maioria dos participantes do congado a composição dessa linguagem artística se dá de forma consciente, pensada como o seguimento de uma tradição em que eles entendem os motivos de usarem aquela roupa ou não entrarem na igreja. Da mesma forma observamos que nem todas as pessoas da comunidade entendem o congado como uma manifestação artística e cultural, mas sim como folclore - que também é uma forma de cultura e arte, mas que simboliza o mito, a lenda.

Por fim, acreditamos que o projeto "Os símbolos das linguagens artísticas do congado de Paula Cândido" cumpriu o intuito de pesquisar, observar, estudar e difundir a importante cultura de uma pequena cidade do interior de Minas Gerais, através de suas características e sua história. No entanto, há todo um campo de outros elementos a serem explorados nos aspectos culturais e sociais do município e da região. Destacamos que toda a manifestação artística é imbuída de sua construção histórica em meio à estrutura social que por vezes exclui e cumpre o papel de hierarquizá-las. A apresentação que ocorre durante a Festa de Nossa Senhora do Rosário une fé, arte e diferentes formas de adoração à santa, propiciando o encontro de culturas, constituindo e reconstruindo suas memórias.

\section{AGRADECIMENTOS}

Os autores do trabalho agradecem o financiamento da pesquisa pela Universidade Federal de Viçosa, por meio do Programa Institucional de Bolsas de Cultura e Arte Universitária - PROCULTURA - UFV.

\section{REFERÊNCIAS}

BATISDE, Roger. Dois Catolicismos. In: As Religiões Africanas no Brasil. 3.ed. São Paulo: Pioneira, 1971.

BRASIL. Plano Nacional de Educação - PNE/Ministério da Educação. Brasília, DF: INEP, 1999.

CANDAU, Joel. Bases antropológicas e expressões mundanas da busca patrimonial: memória, tradição e identidade. Revista Memória em Rede, Pelotas (RS), v. 1, n. 1, p. 43-58, dez. 2009-mar.2010.

COSTA, Marli Lopes da; CASTRO, Ricardo Vieira Alves. Patrimônio imaterial nacional: preservando memórias ou construindo histórias? Rio de Janeiro: UERJ, 2008.

GEERTZ, Clifford. A interpretação das Culturas. 1 ed. 13 reimpressão, Rio de Janeiro: LTC, 2008.

LEITE, Flaviane Lúcia Pereira. Linguagens do vestuário: as transformações na indumentária da Festa de Nossa Senhora do Rosário de Paula Cândido-MG. Dissertação de Mestrado. Mestrado em Patrimônio Cultural, Paisagens e Cidadania - Universidade Federal de Viçosa, 2019.

NERY, Cristiane. Um olhar sobre o Congado das Minas Gerais. Belo Horizonte: UEMG, 2012. 
QUEIROZ, Giane Rena Cardoso. A festa de nossa senhora do rosário de Paula Cândido (MG): Identidade, memória e ritual no Congado e no Reinado. Juiz de Fora: UFJF, 2013

TELLES, Mário Ferreira de Pragmácio. Patrimônio cultural material e imaterial - dicotomia e reflexos na aplicação do tombamento e do registro. In: Políticas Culturais em Revista. n.2.Salvador: UFBA, 2010.

Submetido em: 31/05/2018 Aceito em: 09/10/2019. 